\title{
CDCA8 wt Allele
}

National Cancer Institute

\section{Source}

National Cancer Institute. CDCA8 wt Allele. NCI Thesaurus. Code C126507.

Human CDCA8 wild-type allele is located in the vicinity of 1 p34.3 and is approximately 17 $\mathrm{kb}$ in length. This allele, which encodes borealin protein, is involved in the modulation of cell division. 